\title{
SOSIALISASI PENGOLAHAN MINUMAN FUNGSIONAL DARI TERIPANG DENGAN MENERAPKAN TEKNOLOGI THERMAL DI KAMPUNG MADUNG KELURAHAN KAMPUNG BUGIS KOTA TANJUNGPINANG PROVINSI KEPULAUAN RIAU
}

\section{Socialization of Seacucumber Functional Drink Processing By Applying Thermal Technology In Kampung Madung, Kelurahan Kampung Bugis, Tanjungpinang City, Riau Island Province}

\author{
R. Marwita Sari Putri ${ }^{*}$, Azwin Apriandi ${ }^{1}$, Made Suhandana ${ }^{1}$ \\ ${ }^{1)}$ Jurusan Teknologi Hasil Perikanan, Fakultas Ilmu Kelautan dan Perikanan, Universitas \\ Maritim Raja Ali Haji, Tanjungpinang \\ *Korespondensi : 2012wita@gmail.com
}

\begin{abstract}
ABSTRAK
Universitas Maritim Raja Ali Haji merupakan salah satu Universitas di Provinsi Kepulauan Riau yang memiliki kewajiban untuk mengembangkan industri kecil dan menengah (IKM) dengan bentuk kegiatan pengabdian kepada masyarakat (PKM). Kegiatan PKM ini diharapkan dapat menjadi suatu wadah yang dapat meningkatkan pengetahuan dan keahlian masyarakat sasaran. Adapun mitra yang dipilih merupakan kelompok masyarakat pengolah produk perikanan yang berada di sekitar kampus FIKP UMRAH yaitu di Kampung Madung Kelurahan Kampung Bugis. Adapun permasalahan utama pada mitra yaitu masih kurangnya pengetahuan tentang diversifikasi produk pangan dari pengolahan teripang sehingga hanya dijual dalam bentuk kering dan minyak gamat, padahal hal ini sangat berguna untuk meningkatkan nilai ekonomis dari produk. Solusi utama adalah sosialisasi pengolahan minuman fungsional teripang dengan penerapan teknologi thermal sehingga menghasilkan produk yang bernilai ekonomis dan lebih awet dalam penyimpanan. Metode program ini dibagi menjadi beberapa tahapan yaitu diskusi atau tanya jawab kepada masyarakat sasaran yang akan memberikan kesempatan kepada Mitra untuk melakukan proses pemahaman materi atau menyampaikan gagasan dan permasalahan yang terkait dengan diversifikasi produk olahan teripang khususnya dalam pengolahan minuman fungsional, sosialisasi praktik pengolahan minuman fungsional dari teripang, pembagian buku diversifikasi sebagai suatu bentuk pengetahuan dasar tentang penganekaragaman produk olahan hasil perikanan. Tujuan pengabdian ini adalah meningkatkan pengetahuan tentang penganekaragaman produk hasil perikanan dari teripang dengan menggunakan teknologi thermal. Hasil pengabdian yang ingin dicapai adalah khalayak sasaran dapat mengolah teripang menjadi minuman fungsional dan menerapkannya pada industri/kelompoknya.
\end{abstract}

Kata kunci : diversifikasi produk, minumam fungsional, teripang, teknologi thermal

\begin{abstract}
Riau Islands is one of the provinces that prioritizes the fisheries sector as one of the spearheads of its economy. The industry in this sector is still dominated by small and medium industries (IKM) which are generally engaged in processed fishery products. UMRAH as one of the Universities in the Riau Islands Province has an obligation to help develop small and
\end{abstract}


medium industries (IKM) with community service activities. The selected partners are fishery product processing community groups around the FIKP UMRAH campus. Basically, this program is a form of solutive activity from the campus to partners as the target community. The main problem for partners is the lack of knowledge about food product diversification from sea cucumber processing so that it is only sold in dry form, even though this is very useful to increase the economic value of the product. The main solution is the socialization of the processing of sea cucumber functional drinks with the application of thermal technology on the packaging so as to produce a product that has economic value and is more durable in storage. The method of this program is divided into several stages, namely the determination of cadres, discussions or questions and answers to the target community that will provide an opportunity for Mitra to carry out the process of understanding the material or convey ideas and problems related to the diversification of sea cucumber processed products, the socialization of functional beverage processing practices of sea cucumbers, distribution of pocketbooks as basic knowledge about diversification of processed fishery products. The aim of this service is to increase knowledge about the diversification of fishery products from sea cucumbers by using thermal technology. The result of the service to be achieved is the target audience can process sea cucumbers into functional drinks and apply them to the industry/group.

Keyword: diversification, fuctional drink, seacucumber

\section{PENDAHULUAN}

Teripang merupakan salah satu hewan laut yang tergolong kedalam hewan invertebrata dengan bahasa latinnya holothuroidea atau lebih dikenal dengan nama timun laut. Indonesia termasuk salah satu Negara penghasil teripang, adapun salah satu daerah penghasil teripang adalah Kepulauan Riau. Provinsi Kepulauan Riau termasuk salah satu Provinsi yang memiliki luas lautan hampir 96\% sehingga mempunyai sumberdaya kelautan yang sangat besar. Adapun salah satu Kabupaten yang berada di Provinsi ini yang terkenal sebagai penghasil teripang yaitu Kabupaten Bintan. Jumlah produksi teripang di Kabupaten Bintan cukup banyak, tetapi masih sedikit Unit Pengolahan Ikan yang menghasilkan produk olahan teripang. Berdasarkan Dinas Kelautan dan Perikanan Kabupaten Bintan tahun 2012, bahwa unit pengolahan ikan di Kabupaten Bintan yang mengolah teripang hanya $1,58 \%$ dari total 10 kelompok. Selain itu, teripang sebagai hasil perikanan di Indonesia khususnya di Bintan masih belum dimanfaatkan semaksimal mungkin dalam penerapannya dibidang pangan khususnya dalam pengolahan minuman fungsional

Permasalahan tersebut terletak dari minimnya pengetahuan industri dalam penganekaragaman olahan hasil perikanan. Diversifikasi olahan hasil perikanan dapat meningkatkan nilai ekonomi dan umur simpan produk. Salah satu hasil perikanan yang bisa dijadikan produk diversifikasi adalah teripang menjadi minuman fungsional. Salah satu mitra sasaran dalam melakukan kegiatan ini adalah industri kecil menengah yang terdapat di sekitar Kampus Universitas Maritim Raja Ali Haji. Industri kecil menengah tersebut hanya mengolah teripang dalam bentuk kering dan minyak gamat. Pengolahan teripang menjadi minuman fungsional ini diharapkan dapat dijadikan sebagai salah satu alternatif penganekaragaman produk olahan teripang dibidang pangan dan meningkatkan pendapatan ekonomi mitra sasaran.

Mitra pertama yang menjadi sasaran yaitu kelompok pengolahan teripang ibu Ara. Kelompok ini bergerak dalam bidang usaha pembuatan minyak gamat dan 
pengolahan teripang dalam bentuk kering. Kurangnya ilmu pengetahuan dalam pengolahan teripang menjadi produk pangan yang siap untuk dikonsumsi menjadikan teripang hanya dimanfaatkan oleh kalangan tertentu saja. Berdasarkan paparan diatas menunjukkan bahwa sangat perlu dilakukan sosialisasi penganekaragaman produk olahan teripang dalam bentuk minuman fungsional dengan tujuan untuk meningkatkan nilai ekonomi produk dan memperpanjang masa simpan.

\section{METODE}

\section{Waktu dan Tempat}

Kegiatan dilaksanakan selama 6 bulan, mulai Juni 2019-November 2019 di Kelurahan Kampung Bugis, Kecamatan Tanjungpinang Kota, Kota Tanjungpinang, Provinsi Kepulauan Riau.

\section{Prosedur Pelaksanaan dan Analisis Data Diskusi}

Program kemitraan masyarakat ini dilakukan dalam bentuk diskusi awal atau tanya jawab yang akan memberikan kesempatan kepada mitra sasaran untuk menyampaikan ide atau gagasan dan permasalahan yang terkait dengan diversifikasi produk olahan teripang yang selama ini dilakukan oleh mitra sasaran (minyak gamat dan teripang kering) dan bagaimana cara mengemas produk yang baik. Metode diskusi ini dilakukan dengan tujuan dapat mempunyai dampak positif terhadap pengetahuan yang dimiliki oleh mitra sasaran. Adapun materi yang didiskusikan adalah:

1. Pelatihan cara mendiversifikasi olahan produk teripang

2. Pelatihan cara mengemas produk minuman fungsional teripang

\section{Praktik Pengolahan}

Adapun metode praktik yang akan dilakukan adalah pengolahan dan pengemasan produk. Tujuan pengemasannya disini adalah untuk memperpanjang masa simpan produk olahan.

\section{Pembuatan dokumen diversifikasi produk fungsional hasil perikanan}

Kegiatan ini merupakan kegiatan pembuatan buku penganekaragaman produk dengan melibatkan mitra sasaran dan mahasiswa dalam prosesnya. Dokumen diversifikasi ini diharapkan mampu memberikan sumbangsih kepada mitra sasaran dan mahasiswa untuk menambah ilmu dan pengetahuan di bidang penganekaragaman produk hasil perikanan. Oleh karena itu pada pembuatan dokumen ini harus ditunjang dengan basis penelitian dalam penghitungannya sehingga hasil yang didapatkan pun dapat terstandar dengan baik dan tepat.

\section{HASIL DAN PEMBAHASAN}

\section{Sosialisasi pengolahan minuman fungsional teripang tahap pertama}

Sosialisasi pengolahan minuman fungsional dari teripang yang dilakukan pada mitra sasaran pengolahan teripang bu Ara adalah dengan cara diskusi terlebih dahulu mengenai cara pengolahan minuman fungsional dari teripang dan bagaimana cara mengemas minuman tersebut sehingga siap untuk di minum (ready to eat). Metode diskusi ini adalah untuk memperkenalkan kepada Mitra sasaran bahwa teripang bisa dijadikan sebagai salah satu produk diversifikasi pangan dalam bentuk minuman fungsional. Suasana kunjungan awal kepada Mitra sasaran dengan tujuan akan mensosialisasikam minuman fungsional dari teripang dapat dilihat pada Gambar 1.

\section{Sosialisasi pengolahan minuman fungsional teripang tahap ke dua}

Sosialisasi pengolahan minuman fungsional teripang tahap ke dua ini adalah langsung mempraktekkan cara pengolahan minuman fungsional kepada mitra sasaran. Pengolahan minuman fungsional ini 
langsung dilakukan dirumah ibu Ara yang berlokasi di Kampung Madung. Setelah pengolahan minuman fungsional dilakukan mitra sasaran melakukan uji hedonik (kesukaan) terhadap atribut sensori yang dimiliki oleh minuman fungsional teripang yaitu rasa, warna dan aroma. Uji hedonik dilakukan dengan cara wawancara langsung terhadap mitra sasaran. Uji hedonic minuman fungsional teripang di rumah mitra sasaran dapat dilihat pada Gambar 2.

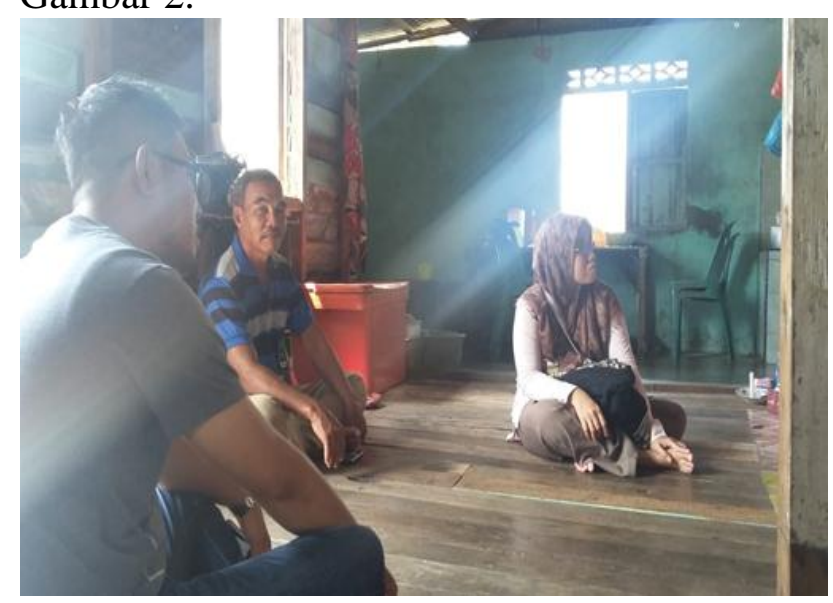

Gambar 1 Kunjungan awal kepada mitra sasaran

Uji hedonik merupakan sebuah pengujian dalam analisa sensori organoleptik yang digunakan untuk mengetahui besarnya perbedaan kualitas diantara beberapa produk sejenis dengan memberikan penilaian, adapun prinsip uji hedonik yaitu panelis diminta tanggapan pribadinya tentang kesukaan atau ketidaksukaannya terhadap komoditi yang dinilai, bahkan tanggapan dengan tingkatan kesukaan atau tingkatan ketidaksukaannya dalam bentuk skala hedonik (Tarwendah et al. 2017). Mitra sasaran diminta untuk menanggapi terhadap atribut sensori yang dihasilkan oleh minuman fungsional teripang. Atribut sensori merupakan kumpulan kata untuk mendeskripsikan karakteristik sensori pada suatu produk pangan, diantaranya adalah warna, rupa, bentuk, rasa, dan tekstur (Hayati et al. 2012). Karakteristik dari kenampakan umum produk meliputi warna, ukuran, bentuk, tekstur permukaan, tingkat kemurnian dan karbonasi produk (Meilgard et al. 2006). Berdasarkan hasil wawancara langsung kepada mitra sasaran terhadap atribut sensori minuman fungsional teripang yang dihasilkan bahwa mitra sasaran memberikan hasil suka terhadap semua atribut sensori minuman fungsional teripang, dimana rasa dari minuman fungsional teripang tidak ada rasa amis yang ditimbulkan oleh teripang, rasa amis teripang hilang karena ada penambahan jahe, rosella serta jeruk. Aroma yang dihasilkan dari minuman ini adalah wangi serai, sedangkan untuk atribut warna pada minuman ini menghasilkan warna merah yang berasal dari rosella yang ditambahkan pada minuman.

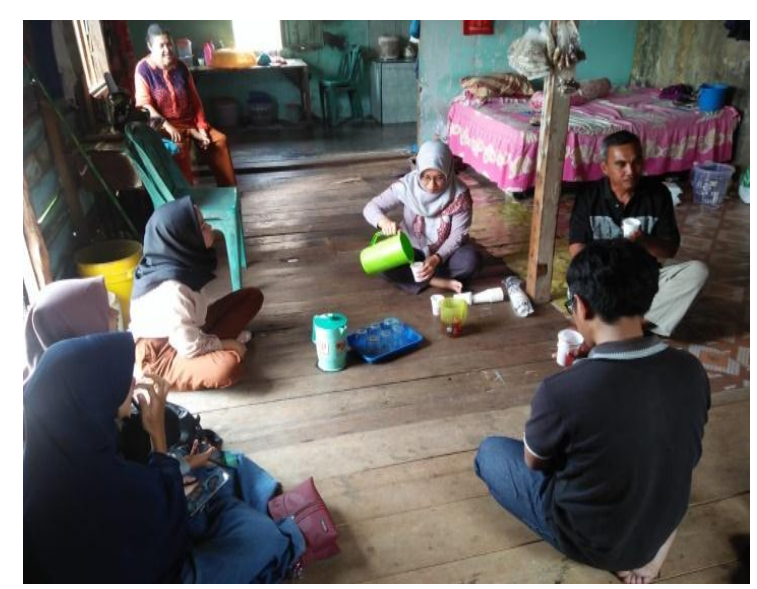

Gambar 2 Uji Hedonik minuman fungsional teripang

\section{Pengolahan minuman fungsional}

Minuman fungsional merupakan salah satu jenis pangan fungsional. Syarat dari minuman fungsional itu adalah dapat memberikan asupan gizi serta dapat diterima secara hedonik oleh konsumen. Dimana arti dari pangan fungsional adalah pangan yang didalamnya terkandung komponen bioaktif. Dengan kemajuan zaman sekarang ini menutut kita untuk memilih makanan itu tidak hanya sekedar mempunyai lezat dan mempunyai kandungan gizi yang bermanfaat bagi tubuh, pemilihan makanan juga didasarkan kepada pengaruhnya terhadap kesehatan 
tubuh. Ada beberapa istilah untuk makanan yang berpengaruh baik terhadap.kesehatan yaitu : :Functional food, Nutraceutical, Pharma food, Designer food, Vita food, Phytochemical, Food aceutical, Health food, Natural food dan Real food (Suter KI. 2013).

\section{Pengolahan Minuman Fungsional \\ Tahap preparasi teripang (Ulfa et al. 2019 dan Sudrajat 2002) yang dimodifikasi}

Teripang yang berukuran $200 \mathrm{~g}$ dipreparasi dan dibuang jeroannya sampai bersih. Kemudian daging teripang yang sudah bersih direbus dengan menambahkan daun pepaya sebanyak $7,5 \%$ (b/v). Pada preparasi teripang ini dilakukan proses perebusan dimana suhu yang digunakan dalam perebusan ini adalah 55$65{ }^{\circ} \mathrm{C}$ selama 60 menit. Setelah selesai dilakukan perebusan sisa kapur yang masih menempel digosok dan disikat sampai bersih. Setelah selesai perebusan tahap 1 daging teripang disaring dengan tujuan menghilangkan kotoran yang masih terlarut. Tahap selanjutnya yaitu tahap perebusan ke 2 dengan suhu yang sama yaitu $55-65{ }^{\circ} \mathrm{C}$ selama 3 jam sehingga daging hancur dan diperoleh filtrat yang berwarna putih berkabut. Teripang yang digunakan sebagaia bahan baku minuman fungsional dapat dilihat pada Gambar 3.

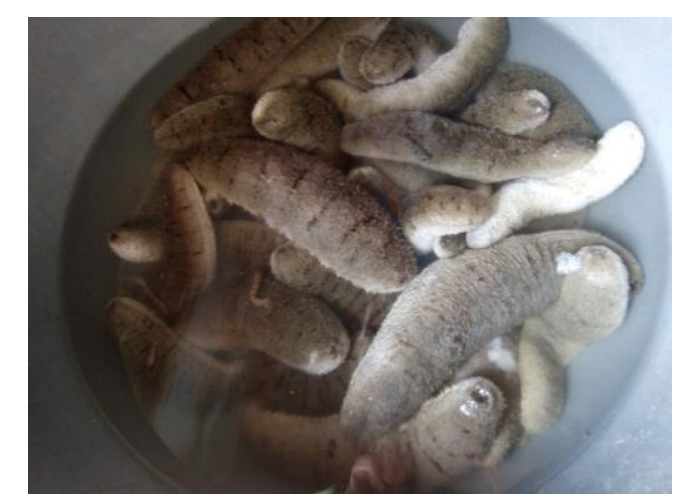

Gambar 3 Teripang sebagai bahan baku minuman fungsional

\section{Tahap formulasi minuman fungsional teripang (Putri et al.2013 dan Ulfa et al. 2019) yang dimodifikasi}

1. Jahe segar dikupas kulitnya dan dicuci dengan air tawar kemudian diblender sampai ukurannya menjadi lebih kecil dengan penambahan air 1:5 (b/v). Sampel disaring menggunakan kain blacu untuk diambil ekstraknya. Penambahan ekstrak jahe dimaksudkan untuk menghilangkan bau amis yang bersal dari teripang.

2. Jeruk dipisahkan dari bijinya kemudian ditambahkan air tawar dengan perbandingan air sebesar 1:5 (b/v). Larutan jeruk disaring menggunakan kain belacu dengan ukuran 22 × $32 \mathrm{~cm}$ hingga diperoleh ekstrak jeruk, kemudian dimasukkan ke dalam botol dan disimpan dalam refrigerator. Penggunaan jeruk dimaksudkan adalah untuk menghilangkan bau amis pada minuman.

3. Serai dipotong hingga berukuran kecil kemudian direbus dengan penambahan air 1:5 (b/v) pada suhu $90{ }^{\circ} \mathrm{C}$ selama \pm 5 menit kemudian disaring dan didapatkan ekstrak serai. Serai biasanya digunakan untuk memberi aroma pada makanan dan minuman dan juga dapat digolongkan sebagai pengawet alami, karena serai mengandung senyawa fitokimia seperti saponin, tannin, alkaloid, flavonoid dan minyak astiri (Umar et al. 2016).

4. Bunga rosella dicuci bersih dan direbus dengan penambahan air 1:5 (b/v) pada suhu $90{ }^{\circ} \mathrm{C}$ selama \pm 5 menit kemudian disaring dan didapatkan ekstrak bunga rosella. Tujuan penambahan bunga rosella ini dalam pembuatan minuman fungsional ini adalah untuk memberikan warna pada minuman ini.

5. Bahan utama dan bahan tambahan dicampur kemudian dilakukan penambahan gula sesuai dengan tingkat kemanisan yang diinginkan. Kemudian dipanaskan dengan suhu $90{ }^{\circ} \mathrm{C}$ dan 
terus diaduk selama 5-10 menit. Kemudian setelah jadi minuman dimasukkan kedalam botol plastik dan didinginkan didalam lemari pendingin. Tabel formulasi minuman fungsional teripang dapat dilihat pada Tabel 1 . Bahan baku yang digunakan dalam pengolahan minuman fungsional teripang dapat dilihat pada.

\section{Pengemasan minuman fungsional teripang}

Kemasan sangat penting pada suatu produk yang mempunyai fungsi sebagai pelindung, selain berfungsi sebagai pelindung kemasan juga berfungsi sebagai daya tarik konsumen terhadap produk yang akan dipasarkan.

Kemasan yang digunakan pada minuman fungsional teripang ini terbuat dari botol plastik. Tujuan penggunaan botol plastik adalah biaya transportasi untuk distribusi jadi lebih murah dan bentuk dari botol plastik beranekaragam yang cendrung disukai oleh konsumen. Adapun warna dari kemasan minumn ini adalah berwarna putih/transparan sehingga konsumen dapat melihat warna dari minuman. Minuman fungsional teripang dapat dilihat pada Gambar 4.

\section{Angka kecukupan gizi minuman fungsional teripang}

Angka Kecukupan Gizi (AKG) atau Recommended Dietary Allowances (DRA) dapat diartikan sebagai tingkat asupan dari nilai gizi yang dapat memenuhi kebutuhan gizi hampir semua orang sehat menurut golongan umur, jenis kelamin, ukuran tubuh dan aktivitas untuk mencapai derajat kesehatan optimal. Dalam masa pertumbuhan asupan gizi yang baik akan menunjang pertumbuhan dan kesehatan tubuh yang lebih baik (Aulia et al. 2016). Kecukupan gizi seseorang dalam mengkonsumsi makanan itu menjadi suatu hal yang perlu diperhatikan. Zat gizi makro yang harus dicukupi itu adalah kecukupan energi, protein, lemak, karbohidrat dan serat makanan yang dibutuhkan tubuh perhari. AKG berguna sebagai patokan dalam penilaian dan perencanaan konsumsi pangan, serta basis dalam perumusan acuan label gizi (Aulia et al. 2016).

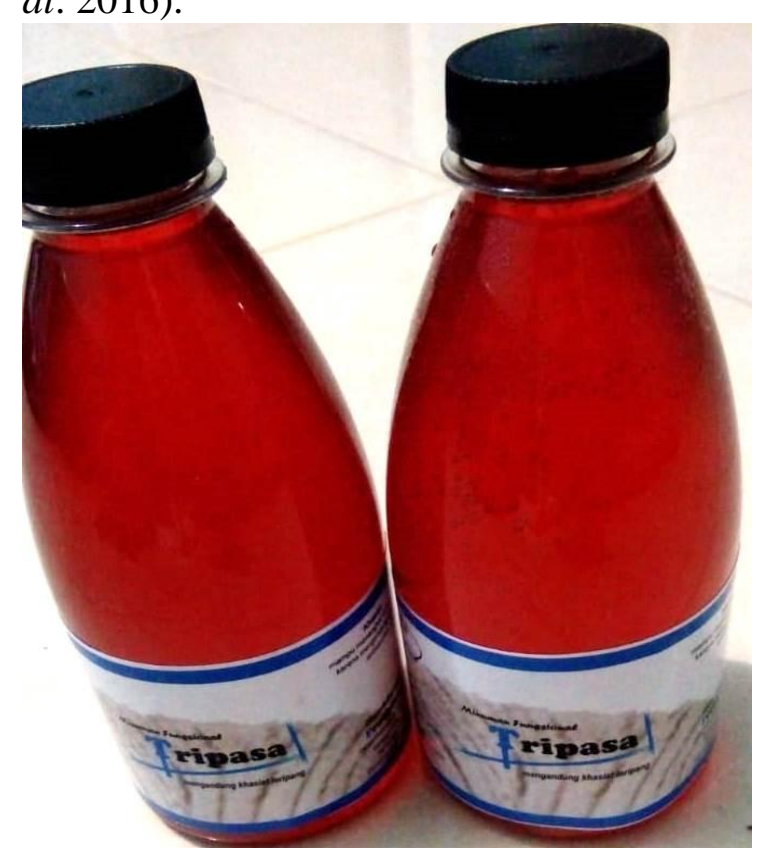

Gambar 4. Minuman fungsional teripang

Angka kecukupan gizi yang dibutuhkan perhari antara laki-laki dan wanita itu berbeda yang tergantung dari beberapa faktor diantaranya umur, jenis kelamin dan aktivitas fisik. Faktor-faktor yang mempengaruhi nilai $\mathrm{AKG}$ yaitu berat badan, tinggi badan, jenis kelamin, usia dan jenis aktivitas seseorang (Supariasa dan Nyoman 2001).

Secara internasional, berbagai istilah digunakan, di Amerika Serikat dan Kanada disebut Dietary Reference Intakes (DRIs),

Tabel 1. Formulasi minuman fungsional teripang (Ulfa et al. 2019)

\begin{tabular}{cccccc}
\hline Bahan Utama $\%$ & \multicolumn{5}{c}{ Bahan-Bahan Tambahan $(\%)$} \\
\hline Teripang & Serai & Rosella & Jeruk & Jahe & Gula \\
20 & 20 & 20 & 10 & 10 & 20 \\
\hline
\end{tabular}


di Uni Eropa disebut Population Reference Intakes, di Jepang disebut Nutrients-Based Dietary Reference Intakes (NBDRIs), WHO menggunakan istilah Recommended Nutrient Intake (RNI), di Filipina digunakan istilah Recommended Energy and Nutrient Intake (RENI), di Australia dan Selandia Baru digunakan istilah Nuterient Reference Values (NRVs). Adapun tujuan dari AKG adalah:

a. Menilai kecukupan gizi pada tingkat perorangan, keluarga, maupun daerah

b. Sebagai perbaikan gizi (makanan tambahan, MP-ASI)

c. Menginterpretasikan data konsumsi makanan perorangan/kelompok

d. Sebagai bahan evaluasi kecukupan persedian pangan baik didaerah maupun nasional

e. Merencanakan program penyuluhan gizi disuatu daerah

f. Merencanakan fortifikasi makanan, sehingga bisa memenuhi kebutuhan gizi

g. Sebagai sarana informasi kepada konsumen pada label kemasan produk

\section{Perhitungan Angka Kecukupan Gizi}

Untuk menghitung angka kecukupan gizi dihitung dari kecukupan energi dan protein, sebab apabila kecukupan energi dan protein telah terpenuhi maka kecukupan zat gizi lainya umumnya telah terpenuhi atau sekurang kurangnya tidak terlalu sukar untuk memenuhinya (Muchtadi. 2009).

Penggunaan nilai energi (kalori) dan nilai protein sudah cukup untuk menggambarkan kecukupan pangan, karena konsumsi kalori terkait erat dengan kemampuan manusia untuk hidup secara aktif sedangkan konsumsi protein dibutuhkan untuk memulihkan sel sel tubuh yang rusak pada usia dewasa atau untuk menjamin pertumbuhan normal pada usia muda (Muchtadi. 2009).

\section{Indikator nilai gizi dalam perhitungan}

\section{AKG}

a. Kecukupan energi

Angka Kecukupan Energi yang dianjurkan menurut Permenkes 2013 dimana pada jenis kelamin laki-laki dalam rentang umur 19-29 tahun adalah sebesar 2725 kkal sedangkan untuk jenis kelamin perempuan dengan rentang umur 19-29 tahun adalah sebesar $2150 \mathrm{kkal}$.

b. Kecupan protein

Adapun Angka Kecukupan Protein yang dianjurkan menurut Permenkes 2013 adalah sebesar 57 gram/orang/hari.

c. Kecukupan lemak

Depkes (1990) menganjurkan konsumsi lemak sebanyak 15\% kebutuhan energi total dianggap baik untuk kesehatan. Adapun jumlah angka kecukuan gizi yang terdapat didalam minuman fungsional teripang hitam dapat dilihat pada Tabel 2.

Tabel 2. Tabel Angka Kecukupan Gizi Pada Minuman Fungsional Teripang Hitam (Ulfa et al. 2019)

\begin{tabular}{lccr}
\hline Parameter & Kandungan & * AKG & $\begin{array}{r}\text { \% } \\
\text { AKG }\end{array}$ \\
\hline Karbohidrat & 29.69 & 375 & 7.91 \\
Protein & 2.66 & 62 & 4.29 \\
Lemak & 0.31 & 91 & 3.44 \\
Energi Total (kkal & & & \\
100 g) & 132.19 & 2725 & 4.84 \\
\hline
\end{tabular}

Keterangan : *Standar AKG umur 19-29 tahun (PERMENKES 2013)

\section{KESIMPULAN}

Pengolahan minuman fungsional di Kampung Madung pada mitra sasaran Ibu Ara dilakukan dengan dua tahap yaitu tahap pertama adalah sosialisasi dalam bentuk diskusi pengenalan kepada mitra sasaran bahwa teripang dapat diolah menjadi minuman fungsional dan jenis kemasan yang bisa digunakan untuk minuman. Sedangkan tahapan kedua adalah proses pengolahan minuman 
fungsional yang langsung di lakukan dirumah mitra sasaran Ibu Ara.

\section{UCAPAN TERIMAKASIH}

Terimakasih diucapkan kepada Universitas Maritim Raja Ali Haji (UMRAH) karena telah mendanai kegiatan Pengabdian Kepada Masyarakat melalui DIPA UMRAH Tahun 2019.

\section{DAFTAR PUSTAKA}

Aulia Z, Rahmadya B, Hersyah HM. 2016. Alat Pengukur Angka Kecukupan Gizi (AKG) Manusia Dengan Menggunakan Mikrokontroler. Seminar Nasional Sains dan Teknologi Fakultas Teknik Universitas Muhammadiyah Jakarta , 8 November 2016

Depkes RI. 1990. Buku Petugas Gizi Pusksmas. Jakarta

[FDA] Food and Drug Administration. 1995. Sanitation, sanitary regulation and voluntary programs. Dalam: Marriott NG, Gravani RB. Principles of Food Sanitation. Ed ke-3. New York: Chapman and Hall.

Muchtadi, D.2009. Pengantar Ilmu Gizi.Alfabeta. Bandung.

Putri RMS, Nurjanah, Tarman K. 2013. Sinergis taurin lintah laut (Discodoris sp.) dan temulawak (Xanthorriza Roxb.) dalam serbuk minuman Fungsional. Jurnal Pengolahan Hasil Perikanan Indonesia 16(1).

Sudrajat, Y. 2002. Teknik penghilangan lapisan kapur pada teripang pasir menggunakan enzim papain. Jurnal Buletin Teknik Pertanian. 7(2): 41-43

Supariasa A, Nyoman I D. 2001. Penilaian Status Gizi. Jakarta: EGC

Tarwendah PI. 2017. Jurnal Review: Studi Komparasi Atribut Sensoris dan Kesadaran Merek Produk Pangan. Jurnal Pangan dan Agroindustri 5 (2): 66-73.

Peraturan Menteri Kesehatan Republik Indonesia. 2013. Angka Kecukupan Gizi Yang Dianjurkan Bagi Bangsa Indonesia. (75) : 5-10.

Ulfa M, Apriandi A, Putri RMS. 2019. Pemanfaatan Teripang Hitam (Holuthuria atra) sebagai minuman fungsional [Skripsi]. Tanjungpinang: Fakultas Ilmu Kelautan dan Perikanan, Universitas Maritim Raja Ali Haji.

Diterima : 18 September 2019

Disetujui : 11 November 2019 